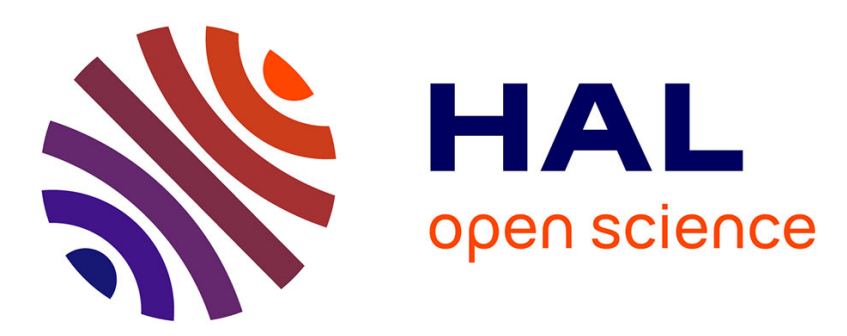

\title{
Modeling Ammonia and Water Co-Adsorption in CuI-SSZ-13 Zeolite Using DFT Calculations
}

\author{
Hugo Petitjean, Céline Chizallet, Dorothée Berthomieu
}

\section{To cite this version:}

Hugo Petitjean, Céline Chizallet, Dorothée Berthomieu. Modeling Ammonia and Water CoAdsorption in CuI-SSZ-13 Zeolite Using DFT Calculations. Industrial and engineering chemistry research, 2018, 57 (47), pp.15982-15990. 10.1021/acs.iecr.8b03821 . hal-01949636

\section{HAL Id: hal-01949636 \\ https://hal.science/hal-01949636}

Submitted on 17 Dec 2018

HAL is a multi-disciplinary open access archive for the deposit and dissemination of scientific research documents, whether they are published or not. The documents may come from teaching and research institutions in France or abroad, or from public or private research centers.
L'archive ouverte pluridisciplinaire HAL, est destinée au dépôt et à la diffusion de documents scientifiques de niveau recherche, publiés ou non, émanant des établissements d'enseignement et de recherche français ou étrangers, des laboratoires publics ou privés. 


\title{
Modeling Ammonia and Water co-Adsorption in $\mathrm{Cu}^{\mathrm{I}}$-SSZ-13 Zeolite Using DFT Calculations
}

\author{
Hugo Petitjean ${ }^{1}$, Céline Chizallet ${ }^{2}$ and Dorothée Berthomieu ${ }^{1 *}$ \\ ${ }^{1}$ Institut Charles Gerhardt Montpellier, UMR 5253 CNRS-ENSCM-UM, Montpellier, France \\ ${ }^{2}$ IFP Energies Nouvelles, Rond-point de l'échangeur de Solaize, BP3, 69360 Solaize, France
}

Corresponding author: dorothee.berthomieu@enscm.fr 


\section{ABSTRACT:}

Cu-SSZ-13 efficiently catalyzes the selective catalytic reduction (SCR) of $\mathrm{NO}$ by $\mathrm{NH}_{3}$ but the structure of the active site and, particularly, the redox state of the copper $(+\mathrm{I}$ or $+\mathrm{II})$ are still debated. This paper focuses on the possible contribution of $\mathrm{Cu}^{\mathrm{I}}$ species with a theoretical investigation of adsorption and co-adsorption of $\mathrm{NH}_{3}$ and $\mathrm{H}_{2} \mathrm{O}$ on $\mathrm{Cu}^{\mathrm{I}}$ species using quantum chemistry and including dispersion forces. The calculations show that $\mathrm{Cu}^{\mathrm{I}}$ clearly migrates upon adsorption of $\mathrm{NH}_{3}$. While $\mathrm{Cu}^{\mathrm{I}}$ is initially in close interaction with the zeolite framework, it preferentially forms coordination bonds with $\mathrm{NH}_{3}$ and interacts with the zeolite in its second coordination sphere. The same tendency is calculated with $\mathrm{H}_{2} \mathrm{O}$, even if the binding energy of $\mathrm{H}_{2} \mathrm{O}$ with $\mathrm{Cu}^{\mathrm{I}}$ is lower than with $\mathrm{NH}_{3}$. All the $\mathrm{Cu}^{\mathrm{I}}$ complexes sit in the cage containing the $8 \mathrm{MR}$. The confined $\mathrm{Cu}^{\mathrm{I}}$ complexes interact with the zeolite framework through several H-bonds donated by the $\mathrm{NH}$ or $\mathrm{OH}$ bonds of the ligands. In the experimental temperature and pressure domain of SCR conditions, calculated phase diagrams show that coordination number of two is predicted for the co-adsorption of $\mathrm{NH}_{3}$ and $\mathrm{H}_{2} \mathrm{O}$ on $\mathrm{Cu}^{\mathrm{I}}$. For pure $\mathrm{H}_{2} \mathrm{O}$, few stable domains for hydrated species containing $\mathrm{Cu}^{\mathrm{I}}$ are calculated in contrast with pure $\mathrm{NH}_{3}$. Finally, the calculated phase diagrams on $\mathrm{Cu}^{\mathrm{I}}$-SSZ-13 are discussed together with the more documented diagrams of $\mathrm{Cu}^{\mathrm{II}}-\mathrm{SSZ}-13$ and recent experimental characterizations, providing a wider picture of the real catalyst in SCR conditions.

ORCID

D. Berthomieu: 0000-0002-3818-105X

C. Chizallet: 0000-0001-5140-8397 


\section{INTRODUCTION}

Transition metal ions form coordination complexes with nuclearities and geometries depending on the coordination preference and oxidation state of the metal, and on the number, nature and affinity of the ligands. Exchanging transition metal ion in zeolites provides a class of very efficient catalysts. ${ }^{1-2} \mathrm{Cu}$-exchanged zeolites and, particularly, $\mathrm{Cu}-\mathrm{SSZ}-13$ were reported as some of the most active catalysts ${ }^{3-7}$ for the selective catalytic reduction (SCR) of $\mathrm{NO}_{x}$ by $\mathrm{NH}_{3}$ or hydrocarbons. ${ }^{8-11}$ The development of such materials requires a better understanding of the reaction mechanisms and a deeper knowledge of zeolite structures in the presence of hosted molecules. Thus, the structure of the catalysts and the evolution of the active species during the catalytic reactions have been analyzed with in situ/operando spectroscopies such as IR, X-ray Absorption Spectroscopies (XAS) and X-ray Emission Spectroscopies (XES). ${ }^{6,}{ }^{12-18}$ The spectroscopic signals are most generally assigned using reference compounds and computational

chemistry, in an iterative process. Such strategies provided indications that isolated $\mathrm{redox} \mathrm{Cu}^{\mathrm{I} / \mathrm{II}}$ species are active sites in the $\mathrm{Cu}-\mathrm{SSZ}-13$ catalyst and provided geometric structures, oxidation states, and structure evolutions of the catalysts during SCR of NO by NH3. ${ }^{12,14,19-25}$ There are strong spectroscopic indications that the valence state, the coordination and the position of the copper metal active site change upon addition of reactants and formation of products during the SCR of $\mathrm{NO}$ by $\mathrm{NH}_{3}$ on $\mathrm{Cu}-\mathrm{SSZ}-13$ catalyst. However, the relationship between the spectroscopic signatures and the structure of the copper species in Cu-SSZ-13 is not straightforward. There is still a debate concerning the location, the coordination number $(\mathrm{CN})$ and the oxidation state of $\mathrm{Cu}$ in $\mathrm{Cu}-\mathrm{SSZ}-13$ during $\mathrm{SCR}$ of $\mathrm{NO}$ by $\mathrm{NH}_{3}$. Among the computational chemistry methods, 
Density Functional Theory-based quantum chemistry is one of the most accurate and useful method to describe material structures containing transition metal ions. It allows predicting how the metal active site structure evolves upon addition of the reactants. Providing very accurate data for materials, DFT-based quantum modeling has to be considered as a theoretical tool to predict solid properties or as a complement of spectroscopic experimental data. ${ }^{22-23,26}$

The adsorption of gas molecules in solid porous catalyst is an essential step in heterogeneous catalysis and the present theoretical study focuses on the adsorption of both $\mathrm{H}_{2} \mathrm{O}$ and $\mathrm{NH}_{3}$ on the Cu-SSZ-13 catalyst. Indeed the SCR of $\mathrm{NO}$ by $\mathrm{NH}_{3}$ leads to the formation of $\mathrm{H}_{2} \mathrm{O}$ and both are strong ligands interacting with copper. Earlier spectroscopic studies of Cu-SSZ-13 upon $\mathrm{NH}_{3}$ adsorption on $\mathrm{Cu}$ revealed the presence of linear $\mathrm{Cu}^{\mathrm{I}}$ species, $\mathrm{O}-\mathrm{Cu}-\mathrm{NH}_{3}$ and $\mathrm{NH}_{3}-\mathrm{Cu}-\mathrm{NH}_{3} .{ }^{13}, 17$ Earlier studies on the impact of the addition of $\mathrm{NH}_{3}$ and $\mathrm{H}_{2} \mathrm{O}$ on $\mathrm{Cu}^{\mathrm{I}}$-exchanged zeolite using experiments combined with quantum chemistry clearly indicated that a migration of $\mathrm{Cu}^{\mathrm{I}}$ may occur upon addition of reactants. ${ }^{13,17}$ Such migrations were reported, in particular for $\mathrm{Cu}^{\mathrm{II}}$, 19,26 and for $\mathrm{Cu}^{\mathrm{I} / \mathrm{II}}-\mathrm{SSZ}-13$ without adsorbent or in the presence of adsorbents. ${ }^{14,24,27-29}$ While a lot of studies were devoted to $\mathrm{Cu}^{\text {II }}$, few of them considered $\mathrm{Cu}^{\mathrm{I}}$. To advance our understanding about SCR with $\mathrm{NH}_{3}$ on $\mathrm{Cu}-\mathrm{SSZ}-13$, a detailed analysis of the adsorption of water and co-adsorption of both $\mathrm{NH}_{3}$ and water on $\mathrm{Cu}^{\mathrm{I}}-\mathrm{SSZ}-13$ is required. The present theoretical investigation aims at describing the position and the coordination structure of $\mathrm{Cu}^{\mathrm{I}}$ in SSZ-13 upon co-adsorption of the two strong ligands involved in $\mathrm{SCR}, \mathrm{H}_{2} \mathrm{O}$ and $\mathrm{NH}_{3}$. To account for the SSZ-13 zeolite framework, periodic unit cells were considered. Based on a recent theoretical study on hydrated $\mathrm{Cu}^{\mathrm{I}}$ clusters, ${ }^{30}$ showing a preference for low coordinated structures, the number of $\mathrm{NH}_{3}$ and $\mathrm{H}_{2} \mathrm{O}$ ligands were limited to four, to calculate the co-adsorption phase diagrams using DFT. This 
choice was also motivated by the well-known decrease of the coordination numbers $(\mathrm{CN})$ from $\mathrm{Cu}^{\text {II }}$ to $\mathrm{Cu}^{\mathrm{I}}$ in $\mathrm{Cu}-\mathrm{SSZ}-13 .{ }^{14,24,31}$

We aim at clarifying the $\mathrm{Cu}^{\mathrm{I}}$ species relevant in the experimental conditions used for SCR of $\mathrm{NO}$ by $\mathrm{NH}_{3}$ in $\mathrm{Cu}^{\mathrm{I}}-\mathrm{SSZ}-13$. The final discussion of the paper revisits the interpretation of recent operando EXAFS experiments in the light of phase diagrams calculated here and in previous studies $^{32}$ to describe the stable copper species in the experimental temperature (basically, between 450 and $623 \mathrm{~K})^{21}$ and pressure domains of the SCR.

\section{COMPUTATIONAL METHODS}

\subsection{Models}

Zeolite SSZ-13 has a chabazite (CHA) structure. It contains 4, 6 and 8 MR (Membered Rings) leading to the formation of large ellipsoidal cages with access through 8MR. Two ellipsoidal cages are connected by a prism cage called D6MR (Double Six Membered Rings). Such arrangement leads to the formation of large windows through $8 \mathrm{MR}$.

A periodic unit cell of SSZ-13 with $\mathrm{O}_{24} \mathrm{Si}_{11} \mathrm{Al}_{1}$ formula was considered, e.g. a Si/Al ratio of 11 . The negative charge induced by the presence of one $\mathrm{Al}$ was compensated by one $\mathrm{Cu}^{\mathrm{I}}$ in order to obtain material charge neutrality $(\mathrm{Cu} / \mathrm{Al}=1)$. All the $\mathrm{SiO}_{4}$ tetrahedra being equivalent, one $\mathrm{Si}$ from the $12 \mathrm{Si}$ was exchanged for one $\mathrm{Al}$. Each tetrahedron involves four non-equivalent $\mathrm{O}$ atoms labelled $\mathrm{O}_{1}, \mathrm{O}_{2}, \mathrm{O}_{3}$ and $\mathrm{O}_{4}$ as shown in Figure 1: $:^{33-34} \mathrm{O}$ adjoining two 4MR, one of the two 4MR being involved in a D6MR, is labelled $\mathrm{O}_{1}$; $\mathrm{O}$ adjoining one 4MR and one 8MR is labelled $\mathrm{O}_{2} ; \mathrm{O}$ adjoining one 4MR of a D6MR, one 6MR of the D6MR and one $8 \mathrm{MR}$ is labelled $\mathrm{O}_{3}$; and $\mathrm{O}$ adjoining two $4 \mathrm{MR}$ and one $6 \mathrm{MR}$ from a D6MR is labelled $\mathrm{O}_{4}$. 
Among all the crystallographic positions for exchanged cations in CHA structure ${ }^{33-34}$ only those accessible to reactants e.g. in the largest cages were considered for copper: these sites are labelled sites I, IV and IV' (Figure 1). Site I is at the center of a 6MR from a D6MR along the [111] direction labelled using the dashed dotted black line in Figure 1. Each of these 6MR contains three $\mathrm{O}_{4}$ and three $\mathrm{O}_{3}$. At this position, a cation that occupies the center of a $6 \mathrm{MR}$ may have a three-fold coordination with three $\mathrm{O}$ atoms.

Site IV is located near a $8 \mathrm{MR}$ window with one $\mathrm{O}_{1}$ and one $\mathrm{O}_{2}$ oriented in the direction of site IV. Site labelled IV' is located near a $8 \mathrm{MR}$ window with two $\mathrm{O}$ atoms, $\mathrm{O}_{2}$ and one $\mathrm{O}_{3}$, directed to this position (Figure 1).
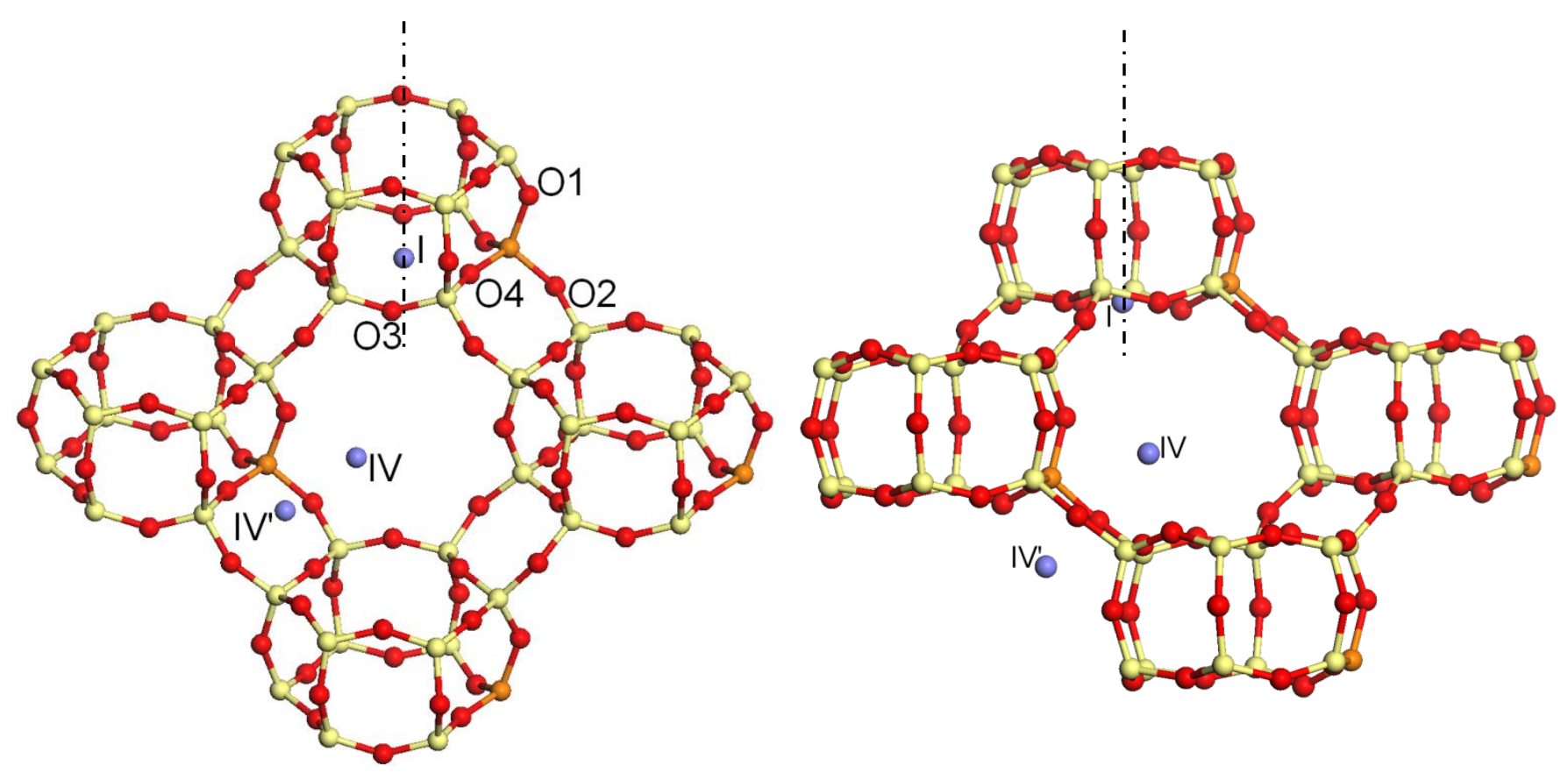

Figure 1. Labels of the framework oxygen atoms and the exchange site positions in the SSZ-13 model unit cell. Sites I are at the center of a 6MR, and sites IV and IV', near a 8MR. Red balls are $\mathrm{O}$, yellow ball are $\mathrm{Si}$, orange ball is $\mathrm{Al}$, and exchange site positions are blue balls. Dashed dotted line is for the D6MR axis. 
The geometries were fully optimized to compare the relative energy values of the Cu ${ }^{\mathrm{I}}-\mathrm{SSZ}-13$ structures.

To calculate phase diagrams, the fully optimized structure $\left(\mathrm{NH}_{3}\right)_{2} \mathrm{Cu}-\mathrm{SSZ}-13$ unit cell parameters were considered as a starting geometry for all the structures containing co-adsorbed ammonia and water and for all the structures containing ammonia or water only. The unit cell parameters $\left(a=9.2968 \AA, b=9.4111 \AA, c=9.2282 \AA, \alpha=93.34^{\circ}, \beta=92.68^{\circ}\right.$ and $\left.\gamma=94.88^{\circ}\right)$ were kept fixed while all atom positions were allowed to relax during geometry optimizations.

Free $\mathrm{NH}_{3}$ and $\mathrm{H}_{2} \mathrm{O}$ were optimized both using the present periodic unit cell and also using a molecular approach.

\subsection{Methods}

Calculations were performed with the hybrid B3LYP exchange-correlation functional, ${ }^{35-36}$ using the massively parallel versions of the periodic ab-initio CRYSTAL09 and CRYSTAL14 codes. $^{37,38}$ B3LYP includes exact Hartree-Fock exchange, which provides more accurate binding energy values in the modeling of copper complexes. ${ }^{39}$ The electronic structures were computed with all-electron Gaussian basis sets: 6-311G(d) for $\mathrm{H}, \mathrm{N}, \mathrm{Al}, \mathrm{Si}$ and $\mathrm{O}$, and TZP $842111 / 631 / 4111$ set for $\mathrm{Cu}$.

The calculation method includes dispersion forces using empirical Grimme correction labelled $\mathrm{D}^{* 40-41}$ for the phase diagrams because it is required to reproduce coordination complex formation of $\mathrm{Cu}^{\mathrm{I}}$ with four $\mathrm{H}_{2} \mathrm{O}$ in the first coordination sphere of copper, as it is calculated with post-Hartree-Fock calculation methods. ${ }^{30}$

Geometry was optimized before frequency calculations with the following criteria: $4.5 \cdot 10^{-4}$ and $3 \cdot 10^{-4}$ a.u. for the gradient thresholds (resp. maximum and RMS), and $1.8 \cdot 10^{-3}$ and $1.2 \cdot 10^{-3}$ a.u. 
for the displacement thresholds (resp. maximum and RMS). The integration grid is a pruned grid with 75 radial points and a maximum number of 974 angular points in regions relevant for chemical bonding (XLGRID keyword). The Brillouin zone was sampled with 8 reciprocal kpoints.

The Hessian matrices were calculated systematically for all the complexes to ensure that the geometries are minima on the potential energy surface. SCF convergence was set to $10^{-7}$ Hartree for the energy. Harmonic vibrational frequencies were calculated at the gamma point. Thermodynamic functions were calculated on the basis of statistical mechanics equations available in the CRYSTAL14 program.

The Gibbs free energies were calculated according to the approach detailed in ref. ${ }^{32}$ by considering the rotational, translational, and vibrational degrees of freedom for gas-phase water and ammonia, and the vibrational degrees of freedom only for the zeolite models. The Gibbs free energy values were calculated at a temperature domain between 398 and $698 \mathrm{~K}$ and a pressure of 1 Atm.

The cumulated adsorption energies $\mathrm{E}$ of $\mathrm{H}_{2} \mathrm{O}$ and $\mathrm{NH}_{3}$ on $\mathrm{Cu}-\mathrm{I} S \mathrm{~S}-13$ were calculated as the electronic energy difference $\mathrm{E}$ (equation (1)).

$$
\mathrm{E}=\mathrm{E}\left[\mathrm{Cu}^{\mathrm{I}}(\mathrm{L})_{\mathrm{x}}-\mathrm{SSZ}-13\right]-\mathrm{E}\left[\mathrm{Cu}^{\mathrm{I}}-\mathrm{SSZ}-13\right]-\mathrm{xE}[\mathrm{L}]
$$

with $\mathrm{L}=\mathrm{H}_{2} \mathrm{O}, \mathrm{NH}_{3}$ and $\mathrm{x}$, the number of ligands $(1 \leq \mathrm{x} \leq 4)$.

The configurations are labeled $(\mathrm{n}, \mathrm{m})$ with $\mathrm{n}$ and $\mathrm{m}$ the number of adsorbed $\mathrm{H}_{2} \mathrm{O}$ and $\mathrm{NH}_{3}$ molecules respectively, with $0 \leq n \leq 4,0 \leq m \leq 4$ and $0 \leq n+m \leq 4$.

All electronic energies of adsorption are corrected from basis set superposition error (BSSE) using correction terms for the energies of the free ligands, water and ammonia, after a thorough study of the counterpoise correction. ${ }^{42}$ For all complexes, we evaluated the BSSE by calculating 
the counterpoise correction for the interaction of each ligand with copper in the complex. For instance, with the adsorption structure $(2,2)$, we calculated the four terms of the counterpoise correction for each of the four ligands (e. g. 16 SCF energy calculations) in interaction with the complex of copper coordinated with the three other ligands in the zeolite. From all these calculations, we evaluated the energy differences when the wavefunction of the partner (ligand or complementary complex) is calculated with its own basis functions or with the full set available in the adsorption structure. Considering all the adsorption structures, for the partner water, the addition of the ghost functions at fixed geometry lowers the energy by $20 \pm 5 \mathrm{~kJ} \cdot \mathrm{mol}^{-1}$; for ammonia, $35 \pm 5 \mathrm{~kJ} \cdot \mathrm{mol}^{-1}$; and for the coordinated copper, $18 \pm 7 \mathrm{~kJ} \mathrm{~mol}^{-1}$. As previously reported ${ }^{43}$ and confirmed here, the stabilization due to the ghost functions strongly depends on the environment of the partners in interaction. In the present case, the counterpoise correction seems delicate to be applied as usual for two main reasons: firstly, from an adsorption complex to another, the coordination geometry of the copper complex changed dramatically and secondly, the complexes are stabilized with several versatile H-bonds between oxygen atoms of the zeolite framework and the $\mathrm{O}-\mathrm{H} / \mathrm{N}-\mathrm{H}$ bonds of the ligands. As the counterpoise correction is known as overestimating the BSSE, we included only part of the counterpoise correction in order to describe the ligand exchange more accurately. As a compromise solution, we neglected the contribution from the coordinated copper part. From our methodical study of the stabilization terms, we assigned an average correction for the energy of the free ligands: $-20 \mathrm{~kJ} . \mathrm{mol}^{-1}$ for free water and $-35 \mathrm{~kJ} \cdot \mathrm{mol}^{-1}$ for free ammonia.

A special attention was paid to investigate the structures of complexes after the addition of 2 $\mathrm{NH}_{3}$ molecules in $\mathrm{Cu}^{\mathrm{I}}-\mathrm{SSZ}-13^{24,}{ }^{44}$ because a series of BOMD (Born Oppenheimer Molecular Dynamics) simulations at $300 \mathrm{~K}$ provided large changes of the initial $\mathrm{Cu}^{\mathrm{I}}$ in the zeolite 
framework and coordination numbers $(\mathrm{CN})$, consistent with experiments and modelings. BOMD simulations were used as a tool to investigate deeply the potential energy surface for the $(0,2)$ combination. Then geometry optimizations were performed. The two $\mathrm{NH}_{3}$ molecules were initially located in the first coordination sphere of optimized $\mathrm{Cu}^{\mathrm{I}}-\mathrm{SSZ}-13$ structures. Then, the most stable optimized structure with $2 \mathrm{NH}_{3}$ molecules in $\mathrm{Cu}^{\mathrm{I}}-\mathrm{SSZ}-13$ (e.g. $(0,2)$ combination) was used as starting point for increasing or decreasing the loading of $\mathrm{NH}_{3}$ in the first coordination sphere of $\mathrm{Cu}^{\mathrm{I}}$, and to generate structures with pure $\mathrm{H}_{2} \mathrm{O}$ and structures containing both $\mathrm{NH}_{3}$ and $\mathrm{H}_{2} \mathrm{O}$. This strategy was used to generate the (n, m) combinations for the calculation of sequential desorption energies and Gibbs free energy diagrams.

\section{RESULTS AND DISCUSSION}

\section{1. $C u-S S Z-13$}

Geometry optimisation of $\mathrm{Cu}^{\mathrm{I}}-\mathrm{SSZ}-13$ led to three structures, $\mathbf{A}, \mathbf{B}$ and $\mathbf{C}$ with $\mathrm{Cu}^{\mathrm{I}}$ located in three different positions in the largest cage (Figure 2). In agreement with previous DFT results, ${ }^{45-}$ ${ }^{46}$ the most stable structure $\mathbf{A}$ has a $\mathrm{Cu}^{\mathrm{I}}$ at site I while the less stable structure $\mathbf{C}$ has a $\mathrm{Cu}$ at site IV' ${ }^{33-34}$ The intermediate structure $\mathbf{B}$ has a $\mathrm{Cu}$ at site IV (Table 1).
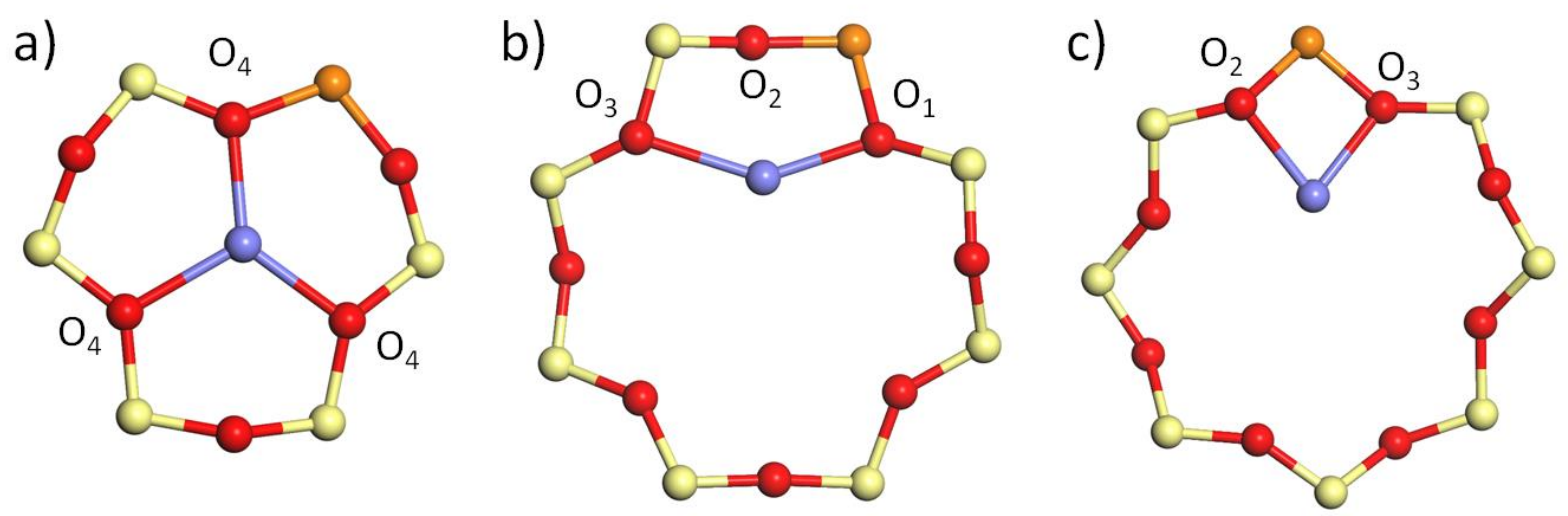
Figure 2. $\mathrm{Cu}^{\mathrm{I}}$ in exchange positions in SSZ-13: a) structure $\mathrm{A}$ with $\mathrm{Cu}^{\mathrm{I}}$ in site $\left.\mathrm{I}, \mathrm{b}\right)$ structure $\mathrm{B}$ with $\mathrm{Cu}^{\mathrm{I}}$ in site $\mathrm{IV}$, and c) structure $\mathrm{B}$ with $\mathrm{Cu}^{\mathrm{I}}$ in site $\mathrm{IV}^{\prime}$. Red balls are $\mathrm{O}$, yellow ball are $\mathrm{Si}$, orange ball is $\mathrm{Al}$, and exchange site positions are blue balls.

These three geometries exhibit strong similarities with previously calculated structures.45-46 The relative energy between structure A and structure B (43 kJ.mol-1) is very similar to the value of $40.5 \mathrm{~kJ} . \mathrm{mol}-1$ previously calculated with a periodic B3LYP method, including a posteriori correction of the long range dispersion.46 Structure $\mathrm{C}$ containing $\mathrm{CuI}$ at site IV' has a relative energy value of 54 kJ.mol-1 (Table 1). It is thus less stable than the structures with $\mathrm{Cu}$ at site I or IV.

The most stable structure A corresponds to $\mathrm{CuI}$ with $\mathrm{CN}$ of 3 (defined as the number of heavy atoms within $2.3 \AA$ of $\mathrm{Cu}$ as in ref.24). In CuI-SSZ-13, the three O4 directed to the center of the 6MR led to the smallest $\mathrm{Cu}-\mathrm{O}$ bonds, while the three other $\mathrm{O} 3$ atoms were directed to the $8 \mathrm{MR}$ with largest $\mathrm{Cu}-\mathrm{O}$ bonds. As reported with other mononuclear cations in 6MR of zeolites, 47 the ring is slightly distorted after optimization because the presence of one Al tetrahedron in the $6 \mathrm{MR}$ induces a dissymmetry, leading to larger Al-O bond lengths and O-Al-O angles in comparison with $\mathrm{Si}-\mathrm{O}$ and $\mathrm{O}-\mathrm{Si}-\mathrm{O}$ (Table $\mathrm{S} 2$ ). The $\mathrm{CN}$ of 3 computed for the structure A is in line with previous modeling studies of zeolites with monocation exchanged in 6MR,2, 24-25, 48 in particular using static calculations for $\mathrm{CuI}$ at site $\mathrm{I}$ of chabazite.45-46 However recent studies including $\mathrm{Ab}$ Initio Molecular Dynamics evidenced many minima with $\mathrm{CN}$ of 2 or 3 on the potential energy surface for $\mathrm{CuI}$ in the $6 \mathrm{MR}$ of the SSZ-13 zeolite.27,24 Such approach goes in the direction of the high mobility experimentally demonstrated for $\mathrm{CuI}$ in the SSZ-13 unit cell changing its coordination, and responsible for a $\mathrm{CN}$, between 2 and 3. 
In the two less stable optimized structures, $\mathrm{CuI}$ is in the $8 \mathrm{MR}$, coordinated to $\mathrm{O} 1$ and $\mathrm{O} 3$ in $\mathrm{B}$ ( $\mathrm{O} 2$ is further than the cut-off distance of $2.3 \AA$ used to define the $\mathrm{CN}$ ), and to $\mathrm{O} 3$ and $\mathrm{O} 2$ in $\mathrm{C}$, both with $\mathrm{CN}$ of 2 . The short $\mathrm{Cu}-\mathrm{O}$ bonds induce a strong deformation of the $8 \mathrm{MR}$ as reflected in the $\mathrm{O} 2-\mathrm{Al}-\mathrm{O} 4$ angle of $100^{\circ}$ and $\mathrm{O} 4-\mathrm{Si}-\mathrm{O} 1$ angle of $104^{\circ}$ in $\mathrm{B}$ that decrease to $\mathrm{O} 2-\mathrm{Al}-\mathrm{O} 4$ angle of $98^{\circ}$ and increases to $\mathrm{O} 4-\mathrm{Si}-\mathrm{O} 1$ of $106^{\circ}$ in $\mathrm{C}$. These changes in the copper interaction with the SSZ-13 framework in B and C, in comparison with A, are most probably responsible for the stability decrease.

In the absence of chemisorbed molecule in the first coordination sphere of $\mathrm{CuI}$, the most stable structure contains $\mathrm{CuI}$ at site I with a $\mathrm{CN}$ of 3 in contrast with an expected $\mathrm{CN}$ of 2 from experiment, and in contrast to the experimental proposal of $\mathrm{CuI}$ positioned in two different sites based on H2-TPR and FTIR studies.6 Recent calculations report different coordination of $\mathrm{CuI}$ at site I in the D6MR.24, 27 These differences reveal that most probably the Potential Energy Surface (PES) for CuI in SSZ-13 contains several minima, as already shown in ref.23 Thus, at finite temperature, the structures $\mathrm{B}$ and $\mathrm{C}$ with $\mathrm{CN}$ of 2 that we calculated for $\mathrm{CuI}$ in $8 \mathrm{MR}$ could play a role and we decided to include the three structures in the thorough study of the ammonia adsorption, even if the energy differences between A, B and C are large.

\section{2. Addition of pure $\mathrm{NH} 3$ and $\mathrm{H} 2 \mathrm{O}$ in $\mathrm{Cu}-\mathrm{SSZ}-13$}

As the linear dicoordinated complexes of $\mathrm{CuI}$ are particularly stable, we started the modeling of adsorption with a deep investigation of the PES for the formation of (NH3)2-CuI-SSZ-13. From the three structures $\mathrm{A}, \mathrm{B}$ and $\mathrm{C}$, the addition of two $\mathrm{NH} 3$ molecules in the first coordination sphere of $\mathrm{CuI}$ led to several minima. Figure 2 shows the most stable $\mathrm{X}, \mathrm{Y}$ and $\mathrm{Z}$ 
optimized geometries (see Table S3 for the geometric parameters). Note that all other structures (for different adsorption stoichiometries) are reported in figure S1.
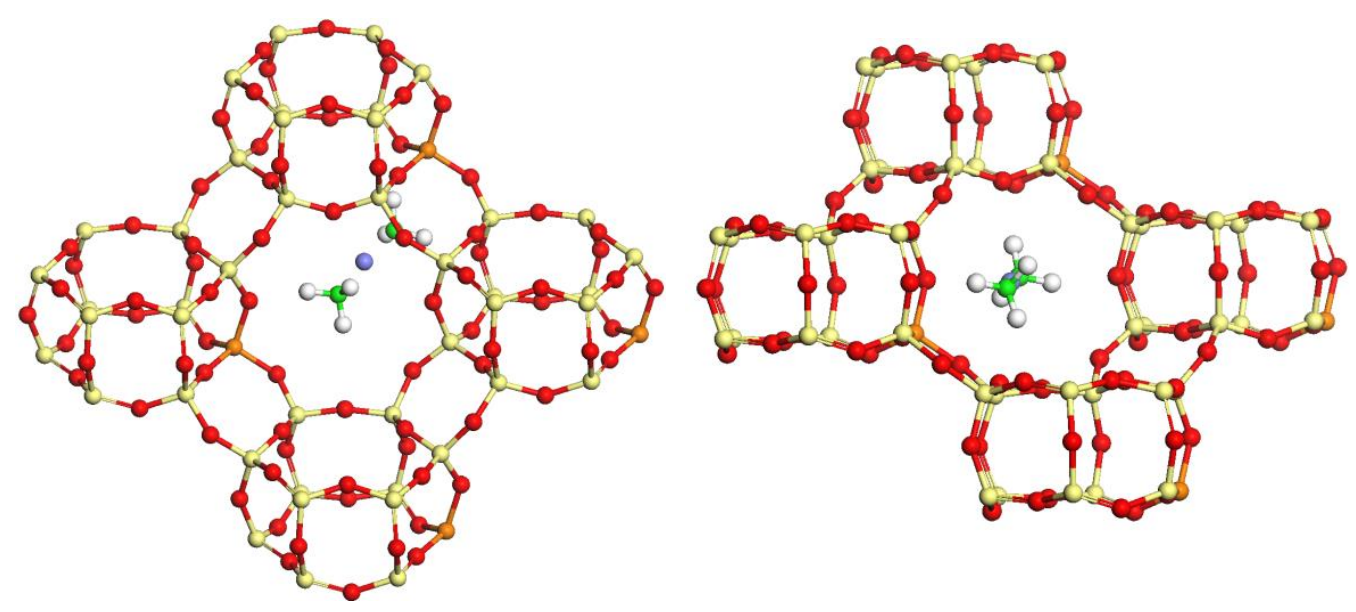

$\mathrm{X}$
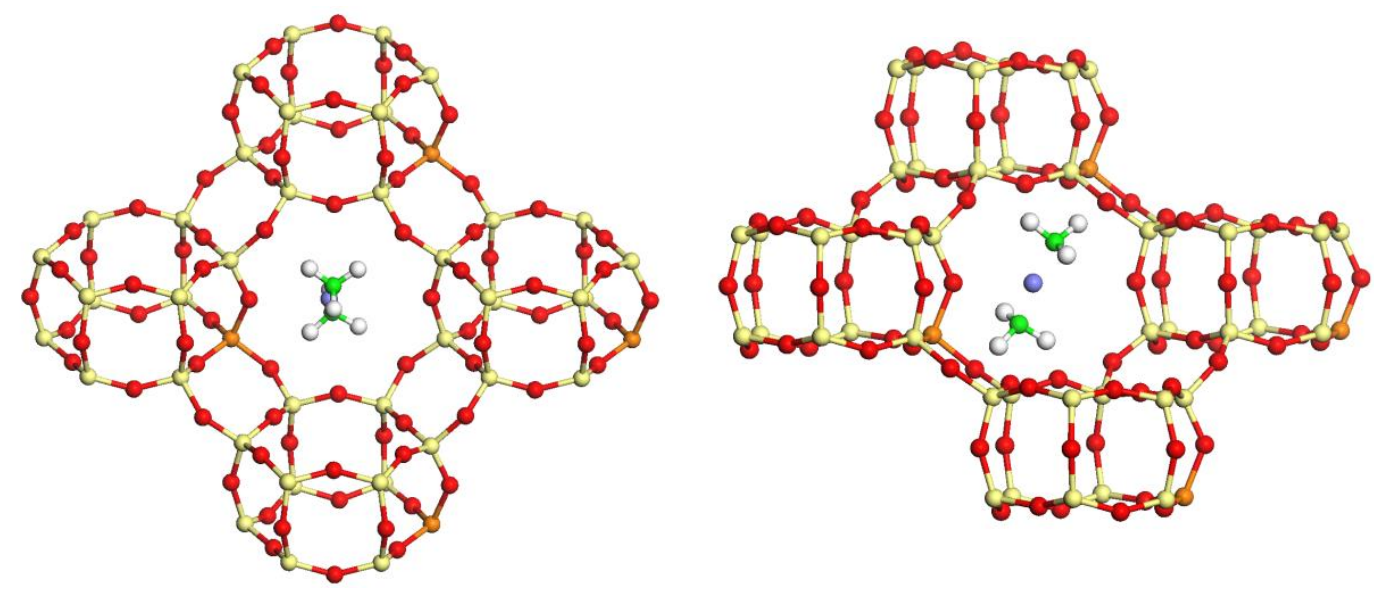

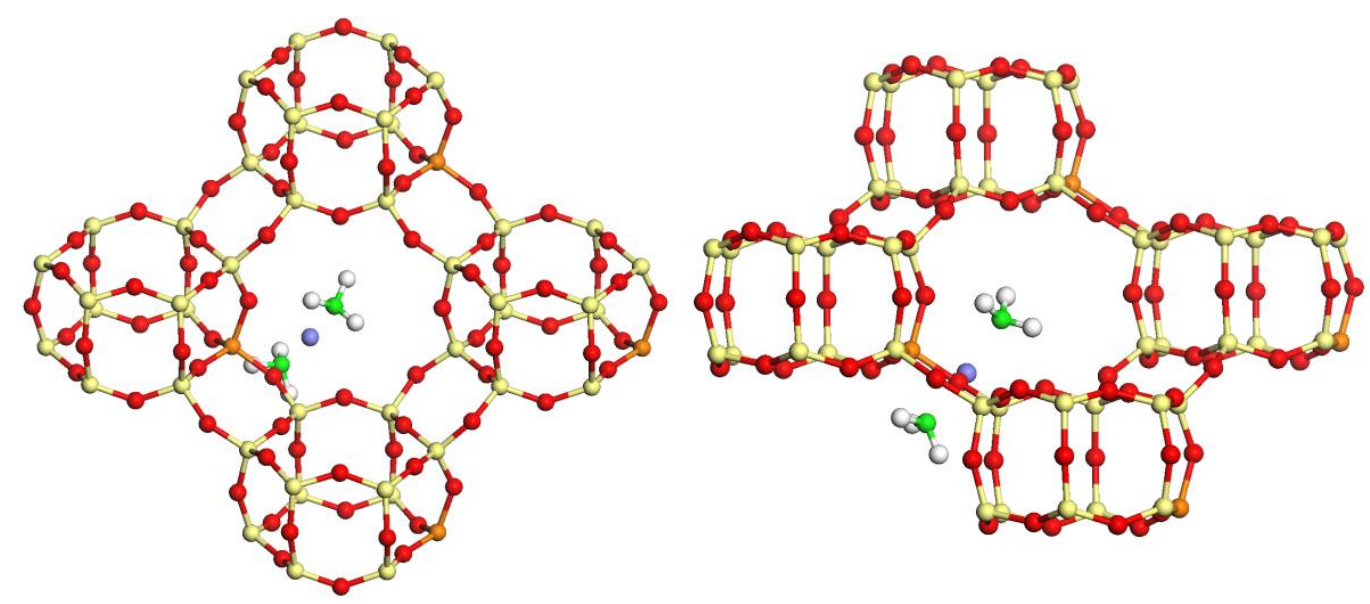

Z

Figure 3. Adsorption structures of $2 \mathrm{NH}_{3}$ in $\mathrm{Cu}^{\mathrm{I}}-\mathrm{SSZ}-13$ unit cell: views of the three optimized structures $\mathbf{X}, \mathbf{Y}$ and $\mathbf{Z}$. Red balls are $\mathrm{O}$, yellow ball are Si, orange ball is Al, green are $\mathrm{N}$ and blue ball are $\mathrm{Cu}^{\mathrm{I}}$.

Upon addition of two NH3 molecules, copper exchanges its framework oxygen ligands with NH3 ligands and moves toward the 8MR window of the SSZ-13. In the three most stable optimized geometries $\mathrm{X}, \mathrm{Y}$ and $\mathrm{Z}, \mathrm{CuI}$ gets far away from the zeolite walls and interacts with the zeolite through its second coordination sphere. This is illustrated by a significant increase of the $\mathrm{Cu}$...Al bond distance larger than $3 \AA$. For the three geometries, copper is twofold-coordinated to two NH3 molecules (Table S3) with $\mathrm{Cu}-\mathrm{N}$ below $2 \AA$. The energy difference between the two most stable structures $\mathrm{X}$ and $\mathrm{Y}$ is $19 \mathrm{~kJ} . \mathrm{mol}-1$ using B3LYP (Table S3). This is significantly smaller than the energy difference of $43 \mathrm{~kJ}$. mol-1 between the structures A and B without NH3 (Table S1).

The most stable structure is the $\mathrm{X}$ structure, as already reported.17, 49 In structure $\mathrm{X}$, the two short $\mathrm{Cu}-\mathrm{N}$ bonds are of around $1.94 \AA$, in agreement with recent computational results. 24 The $\mathrm{N}-\mathrm{Cu}-\mathrm{N}$ angle (calculated below $176^{\circ}$ ) is rather linear, in line with a two-fold coordination. Each 
of the two NH3 molecules establishes a short hydrogen bond with oxygen atoms of the zeolite framework (H...O distance of 2.03 and $1.95 \AA$ A respectively).

The addition of two $\mathrm{H} 2 \mathrm{O}$ molecules in CuI-SSZ-13 led to a structure very similar to the structure $\mathrm{X}$ calculated with $\mathrm{NH} 3, \mathrm{CuI}$ is located in the $8 \mathrm{MR}$ and has a $\mathrm{CN}$ of 2 . Each of the two $\mathrm{H} 2 \mathrm{O}$ molecule has at least one $\mathrm{H} . . \mathrm{O}$ bond length distance with $\mathrm{O}$ from the zeolite framework below $2 \AA$. The $\mathrm{O}-\mathrm{Cu}-\mathrm{O}$ angle is below $171^{\circ}$, in line with a linear $\mathrm{O}-\mathrm{Cu}-\mathrm{O}$ structure.

The addition of 3 and $4 \mathrm{NH} 3$ in the first coordination sphere of $\mathrm{CuI}$ follows the behavior evidenced with the diammino complex. $\mathrm{CuI}$ remains in the $8 \mathrm{MR}$ window and adopts structures without any symmetry (nor $\mathrm{C} 2 \mathrm{v}$, nor $\mathrm{Td}$ for $(0,3)$ and $(0,4)$ configurations, respectively). Each $\mathrm{NH} 3$ has at least one short $\mathrm{H} . . . \mathrm{O}$ distance with $\mathrm{O}$ from the zeolite framework, depicting the existence of hydrogen bonds. Qualitatively similar results are obtained for the addition of 3 and 4 $\mathrm{H} 2 \mathrm{O}$ molecules.

Finally, we studied the unfavorable addition of one molecule per $\mathrm{CuI}$ site to fully describe the adsorption scheme. The addition of one NH3 in CuI-SSZ-13 leads to the formation of a complex with $\mathrm{CuI}$ and $\mathrm{NH} 3$ located in the $8 \mathrm{MR}$ and close the $\mathrm{O} 4$ atom of the $\mathrm{Al}$ tetrahedron in the $6 \mathrm{MR}$, with a $\mathrm{Cu}-\mathrm{O} 4$ bond length in the range of $1.98 \AA$, similar to the $\mathrm{Cu}-\mathrm{N}$ bond length, a $\mathrm{Cu}$... $\mathrm{Al}$ distance in the range of $4.4 \AA$ and a O-Cu-N angle in the range of $160^{\circ}$. This structure is slightly different from the previous reported structure having a short $\mathrm{Cu}$...Al distance in the range of $2.78 \AA .24$

Similarly to the adsorption of one NH3, the adsorption of one $\mathrm{H} 2 \mathrm{O}$ induces a displacement of $\mathrm{CuI}$ in the $8 \mathrm{MR}$ in SSZ-13. The formation of a complex with $\mathrm{CuI}$ and $\mathrm{H} 2 \mathrm{O}$ located in the $8 \mathrm{MR}$ and close the $\mathrm{O} 3$ atom of Si tetrahedra in the $6 \mathrm{MR}$ was calculated. $\mathrm{A} \mathrm{Cu}-\mathrm{O}$ bond length in the range of $2.01 \AA$ different to the $\mathrm{Cu}-\mathrm{O}$ bond length of $1.91 \AA$, a $\mathrm{Cu}$...Al distance in the range of 
$4.28 \AA$ and an $\mathrm{O} 3-\mathrm{Cu}-\mathrm{O}$ angle in the range of $172^{\circ}$ and the two $\mathrm{H}$ atoms very close to two $\mathrm{O}$ atoms from the zeolite framework (bond distances below $2 \AA$ : 1.78 and $1.98 \AA$ ) were computed. Present structure is different from the previous reported structure having a $\mathrm{O} 3-\mathrm{Cu}-\mathrm{O}$ angle in the range of $172^{\circ}$ and a $\mathrm{O} 4-\mathrm{Cu}-\mathrm{O}$ angle in the range of $97^{\circ}$ and a short $\mathrm{Cu} . . . \mathrm{Al}$ distance in the range of $2.79 \AA .24$ The difference between the two structures are in line with a flat PES that may contain several minima, as previously reported.14

Figure 4 shows the B3LYP-D* cumulated adsorption energies of $\mathrm{H} 2 \mathrm{O}$ and $\mathrm{NH} 3$ respectively on CuI-SSZ-13 (exact values in Table S4). The present NH3 and H2O adsorption energy values are smaller than previous reported values, most probably because the present quantum calculation method is different and because the calculated configurations exhibit different structures, in contrast with previous studies.14, 22, 24, 28, 45

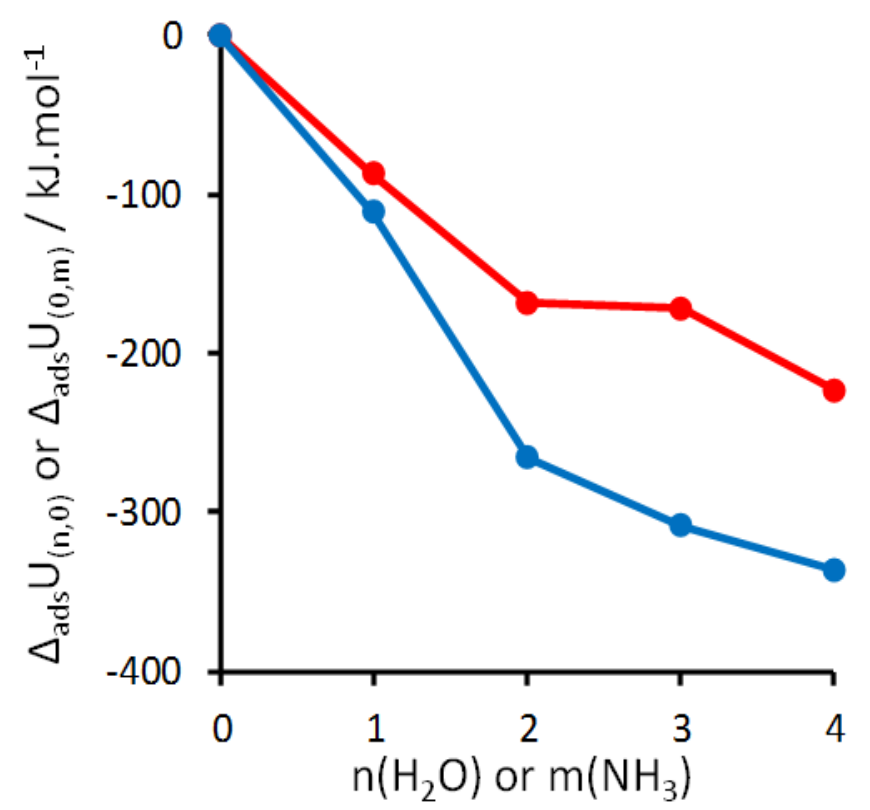

Figure 4. Adsorption of $\mathrm{H}_{2} \mathrm{O}$ or $\mathrm{NH}_{3}$ on $\mathrm{Cu}^{\mathrm{I}}$-SSZ-13: cumulated adsorption energies of $\mathrm{n}_{2} \mathrm{O}$ (red line) or $\mathrm{m} \mathrm{NH}_{3}$ (blue line) on $\mathrm{Cu}^{\mathrm{I}}-\mathrm{SSZ}-13$ complexes (n being the number of water molecules and $\mathrm{m}$, the number of ammonia molecules per $\mathrm{Cu}^{\mathrm{I}}$ ). 
As expected with $\mathrm{Cu}^{\mathrm{I}}$, the ammino complexes are much more stable than the aquo complexes. In comparison with $\mathrm{Cu}^{\mathrm{II}}-\mathrm{SSZ}-13,{ }^{24,32}$ the cumulated adsorption energies are similar for one or two ligand molecules but they stagnate when further molecules are coordinated: for $\mathrm{Cu}-\mathrm{I} S \mathrm{SZ}-13$, the complexes with 2 molecules (linear dicoordinated structures) are particularly stable, whereas higher coordinated species are stable for $\mathrm{Cu}^{\mathrm{II}}$.

\section{3. Co-adsorption of $\mathrm{NH}_{3}$ and $\mathrm{H}_{2} \mathrm{O}$ on $\mathrm{Cu}$-SSZ-13}

The energy diagrams of the co-adsorptions of $\mathrm{NH}_{3}$ and $\mathrm{H}_{2} \mathrm{O}$ were calculated from addition (or elimination) of ammonia and water ligands (L) on the $\mathbf{X}$ structure. All the combinations were optimized for $\mathrm{NH}_{3}$ and $\mathrm{H}_{2} \mathrm{O}$ and only the most stable structures are reported (Table S5, Figure $\mathrm{S} 1)$. Whatever the configurations, $\mathrm{Cu}^{\mathrm{I}}$ is located in the $8 \mathrm{MR}$ window. The $\mathrm{Cu}$...Al distance varies in a large extent from 3.38 to $4.96 \AA$, evidencing that, upon adsorption of water and/or ammonia, copper complexes move a lot in the channel containing the $8 \mathrm{MR}$, either in position or in orientation.

The $(n, m)$ configurations were used to build the thermodynamic stability domains of the adsorption of $\mathrm{NH}_{3}$ and $\mathrm{H}_{2} \mathrm{O}$ with respect to $\mathrm{NH}_{3}$ and $\mathrm{H}_{2} \mathrm{O}$ partial pressure, respectively. The phase diagrams for pure $\mathrm{NH}_{3}$ and $\mathrm{H}_{2} \mathrm{O}$ are given in Figure 5 . 

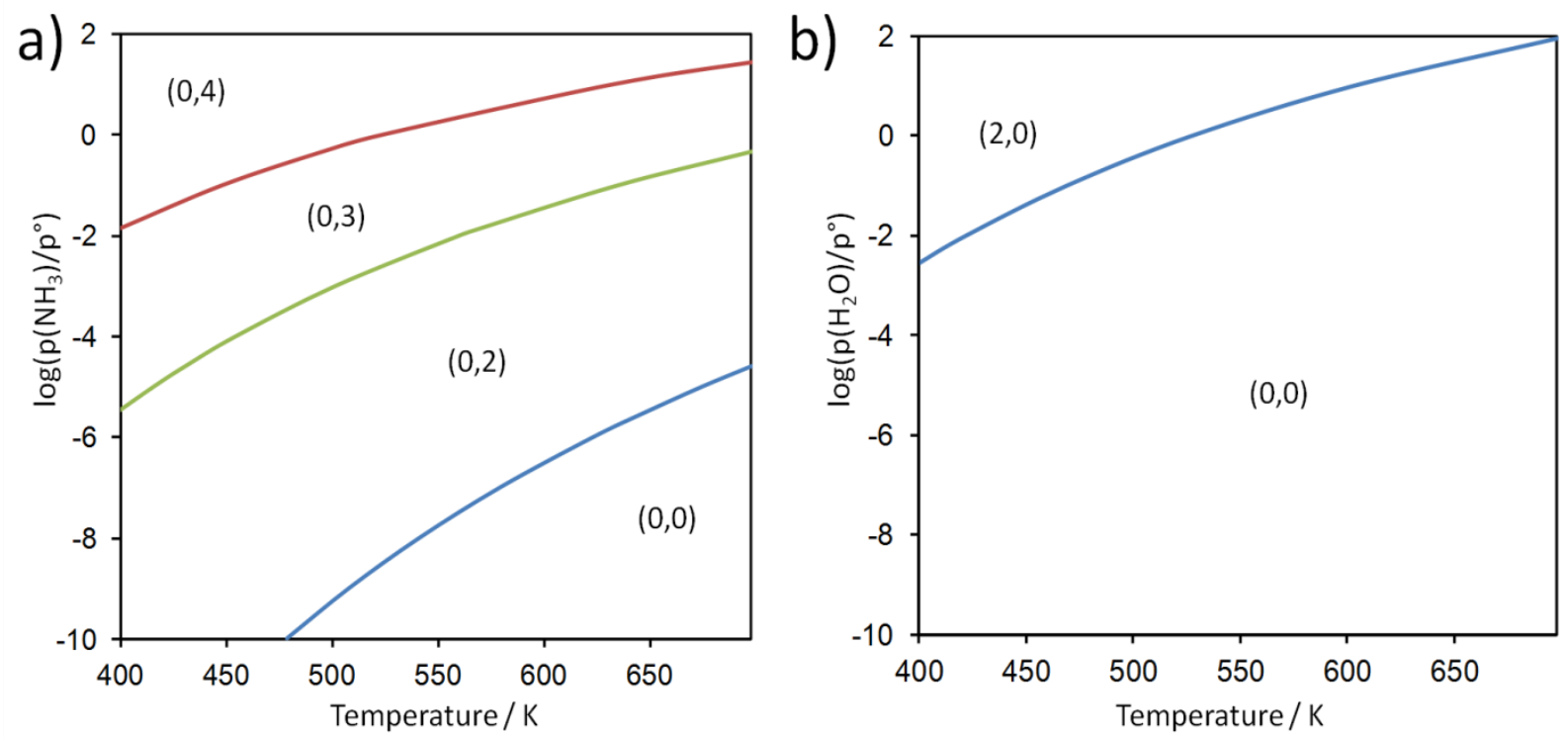

Figure 5. Phase diagrams of $\mathrm{Cu}^{\mathrm{I}}-\mathrm{SSZ}-13$ in presence of ammonia or water: a) pure $\mathrm{NH}_{3}$ adsorption on $\mathrm{Cu}^{\mathrm{I}}-\mathrm{SSZ}-13$, (b) pure $\mathrm{H}_{2} \mathrm{O}$ adsorption on $\mathrm{Cu}^{\mathrm{I}}-\mathrm{SSZ}-13$. The $(\mathrm{n}, \mathrm{m})$ couple in each stability domain gives the number of water molecules (n) and the number of ammonia molecules (m) per $\mathrm{Cu}^{\mathrm{I}}$. Calculated with the B3LYP-D* functional and a compensation accounting for the BSSE.

The predicted phase diagram for pure NH3 exhibits similar tendencies to the one recently calculated49 except that the $(0,1)$ configuration is absent in the present study and the stability domain for the $(0,2)$ configuration is larger using B3LYP-D* as done in the present study.

The predicted phase diagram for pure $\mathrm{H} 2 \mathrm{O}$ indicates very few stability domains, whit only one configuration $(2,0)$ that would exist in the range of experimental SCR conditions. Different phase diagram, with $(0,0)$ and $(1,0)$ configurations only, was calculated in the presence of pressure of $\mathrm{O} 2$, thus accounting for the possible transformation of $\mathrm{CuI}$ into $\mathrm{CuII} .24$

Finally, the phase diagram for the co-adsorption of $\mathrm{NH} 3$ and $\mathrm{H} 2 \mathrm{O}$ (at $\mathrm{p}(\mathrm{H} 2 \mathrm{O})=10-2$ bar and at $\mathrm{p}(\mathrm{NH} 3)=10-3$ bar) in Figure 6 (a) indicates that the stability domains are very similar at low 
pressure of water and without water. This result illustrates the dominant role of ammonia with respect to water, which is also quasi absent from the CuII-SSZ-13 diagram using similar representation conditions reported in ref.32
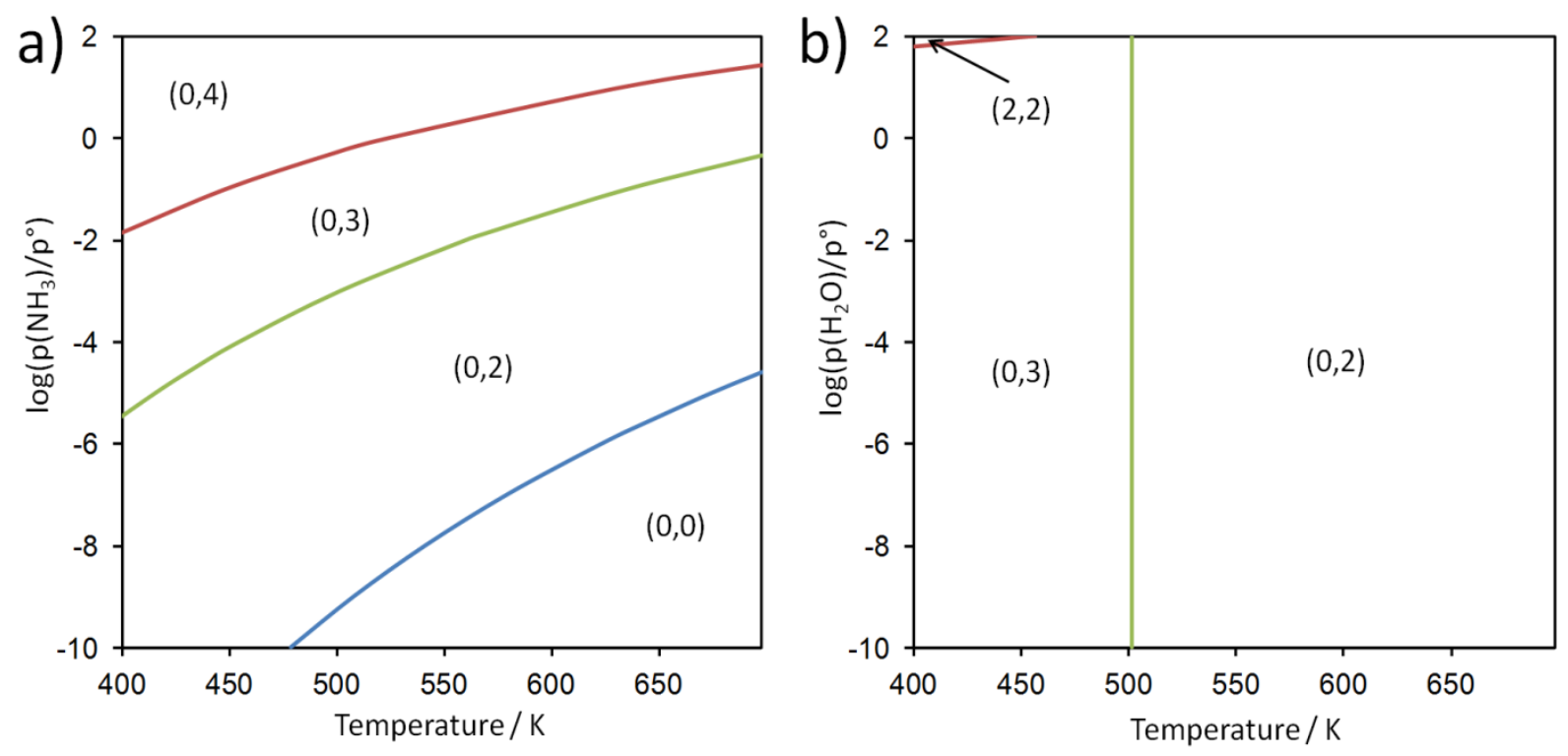

Figure 6. Phase diagrams of co-adsorption of $\mathrm{NH}_{3}$ and $\mathrm{H}_{2} \mathrm{O}$ on $\mathrm{Cu}^{\mathrm{I}}-\mathrm{SSZ}-13$, for (a) $\mathrm{p}\left(\mathrm{H}_{2} \mathrm{O}\right)=10^{-}$ ${ }^{2}$ bar and (b) $\mathrm{p}\left(\mathrm{NH}_{3}\right)=10^{-3}$ bar. The $(\mathrm{n}, \mathrm{m})$ couple in each stability domain gives the number of water molecules (n) and the number of ammonia molecules $(\mathrm{m})$ per $\mathrm{Cu}^{\mathrm{I}}$. Calculated with the B3LYP-D* functional and a compensation accounting for the BSSE.

According to the calculated phase diagrams, there is no stable domain for the adsorption of one $\mathrm{NH}_{3}$ nor for one $\mathrm{H}_{2} \mathrm{O}$ in $\mathrm{Cu}^{\mathrm{I}}-\mathrm{SSZ}-13$. This result differs from the recent results for $\mathrm{NH}_{3}{ }^{49}$ and for $\mathrm{H}_{2} \mathrm{O}^{24}$ The 14 calculated $(\mathrm{n}, \mathrm{m})$ configurations (Table S5) indicate that $\mathrm{Cu}^{\mathrm{I}}$ is surrounded by $\mathrm{H}_{2} \mathrm{O} / \mathrm{NH}_{3}$ in its first coordination sphere sites in the channel containing the $8 \mathrm{MR}$ where its $\mathrm{CN}$ is calculated between 4 and 1. According to the calculated energy diagrams for the co-adsorption of $\mathrm{NH}_{3}$ and $\mathrm{H}_{2} \mathrm{O}$ on $\mathrm{Cu}^{\mathrm{I}}-\mathrm{SSZ}-13$, a CN of 2 is predicted, above $500 \mathrm{~K}$ and below $500 \mathrm{~K}$ (Figure 6) at 
a pressure of water above 60 bars. At low pressure of water and below $500 \mathrm{~K}$, a $(0,3)$ configuration with a $\mathrm{CN}$ of 3 is predicted.

The calculated phase diagrams for SSZ-13 exchanged with $\mathrm{Cu}^{\mathrm{I}}$ (present study) and $\mathrm{Cu}^{\mathrm{II}}$ (ref. ${ }^{32}$ ) are used in the following discussion to better understand how the copper $\mathrm{CN}$ evolves in the experimental conditions. We will focus on the treatment of the $\mathrm{Cu}-\mathrm{SSZ}-13$ catalyst before the SCR experiments, and more precisely on the two first steps: the thermal dehydration of the copper-exchanged zeolite and the adsorption of ammonia.

To study the dehydration of the catalyst, Doronkin et al. ${ }^{32}$ quantified by in situ EXAFS the evolution of the $\mathrm{CN}$ of copper as a function of the dehydration temperature, for an estimated residual partial pressure of $10^{-5}$ bar. According to the thermodynamic diagram shown in Figure 5-(b), in these conditions $\mathrm{Cu}^{\mathrm{I}}$ is always adsorbate-free, so that its $\mathrm{CN}$ is expected to be constant at three (the three ligands being framework oxygen atoms). This means that the thermal evolution of the coordination number is mainly driven by the behavior of $\mathrm{Cu}^{\mathrm{II}}$, which was indeed explained by periodic ab initio calculations in ref. ${ }^{32}$. Experimentally, below $400 \mathrm{~K}$ the average $\mathrm{CN}$ of copper was close to 4.3 and dropped at 3.7 above $400 \mathrm{~K}$, which is only partially rendered by the theoretical predictions made for $\mathrm{Cu}^{\mathrm{II}} \cdot{ }^{32}$ Indeed, considering the existence of $\mathrm{Cu}^{\mathrm{II}}$ only does not explain the appearance of $\mathrm{CN}$ lower than 4 in these temperature conditions. Considering the co-existence between $\mathrm{Cu}^{\mathrm{II}}$ (with $\mathrm{CN}=4$ ) and $\mathrm{Cu}^{\mathrm{I}}$ species (with $\mathrm{CN}=3$ ) better explains this feature. Above $673 \mathrm{~K}$ experimentally, the $\mathrm{CN}$ of copper further drops at 3.0, which could only be explained by the predominance of $\mathrm{Cu}^{\mathrm{II}}$ at the $8 \mathrm{MR}$ site in these conditions. ${ }^{32}$ Now, such a $\mathrm{CN}$ is also compatible with the $\mathrm{CN}$ we quantify here for $\mathrm{Cu}^{\mathrm{I}}$ free from adsorbates. Note however that the amount of $\mathrm{Cu}^{\mathrm{I}}$ is likely very low in these dehydration conditions, considering the quasiabsence of the XANES features typical of $\mathrm{Cu}^{\mathrm{I}}$ (prominent peak at the rising edge at $\left.8983 \mathrm{eV}\right){ }^{32}$ 
Adding ammonia in the feed $\left(10^{-3}\right.$ bar $)$ was observed to promote the reduction of part of the $\mathrm{Cu}^{\mathrm{II}}$ species into $\mathrm{Cu}^{\mathrm{I}}$, in agreement with previous findings, ${ }^{29}$ in particular at increasing temperatures, and in the absence of water. When water was co-fed $\left(10^{-2}\right.$ bar) with ammonia, very similar trends were recorded for what regards ammonia retention, but the $\mathrm{Cu}^{\mathrm{II}} / \mathrm{Cu}^{\mathrm{I}}$ ratio was affected, water acting as an inhibitor of the reduction by ammonia. In these conditions, our current calculations predict the same behavior of $\mathrm{Cu}^{\mathrm{I}}$ whatever the presence or absence of water, with respect to the nature of the coordination sphere. This was also the case for $\mathrm{Cu}^{\mathrm{II}}{ }^{32}$ From EXAFS, the coordination number of copper decreases as the temperature increases, reaching a minimal value of 2 for a critical temperature that depends on the absence / presence of water, being equal to about $500 \mathrm{~K} / 623 \mathrm{~K}$ respectively. Our calculations for $\mathrm{Cu}^{\mathrm{I}}$ predict the desorption of one ammonia molecule at $500 \mathrm{~K}$ in these conditions (Figure 6a), leading to a decrease of the coordination number from 3 to 2 (the ligands being ammonia molecules only, even for the highest temperatures sampled). This is in excellent agreement with the experimental observation made in the absence of water. ${ }^{32}$ In the presence of water, the shift of the critical value at higher temperature $(623 \mathrm{~K})$ is compatible with a non-negligible role of $\mathrm{Cu}^{\mathrm{II}}$ in these conditions. Altogether, the combined consideration of the thermal stability of $\mathrm{Cu}^{\mathrm{II}}$ and $\mathrm{Cu}^{\mathrm{I}}$ species thanks to the thermodynamic diagrams provides a unified view of the reactions taking place as a function of the temperature. Note however that according to our predictions, ammonia is expected to be present in the coordination sphere of $\mathrm{Cu}^{\mathrm{I}}$, whatever the temperature. This is in contradiction with Linear Combination Analysis of XANES spectra as provided in ref. ${ }^{32}$ suggesting the dominance of such species above $673 \mathrm{~K}$. We can indeed not exclude the existence of a distribution of species rather than the existence of a single one, our thermodynamic diagrams providing a very discrete insight in a phenomenon that is actually more statistical than depicted by the diagrams. 


\section{CONCLUSIONS}

The present theoretical investigation aims at investigating configuration structures of mononuclear $\mathrm{Cu}^{\mathrm{I}}$ in SSZ-13 zeolite involved in SCR catalytic reactions, through different $\mathrm{NH}_{3}$ and $\mathrm{H}_{2} \mathrm{O}$ pressures and different temperatures. Calculated structures using B3LYP functional and localized basis sets clearly show that in large pores containing $8 \mathrm{MR}, \mathrm{Cu}^{\mathrm{I}}$ is surrounded by $\mathrm{NH}_{3} / \mathrm{H}_{2} \mathrm{O}$, with a strong preference for $\mathrm{NH}_{3}$ in its first coordination sphere. The calculated cumulated adsorption energies clearly predict a regular decrease of the absolute adsorption energy values while the number of ligands in the first coordination shell of $\mathrm{Cu}^{\mathrm{I}}$ decreases. The 8MR windows being large, the formation of complexes with different structures (minima) on the PES are most probably possible. The $\mathrm{NH}_{3}$ and $\mathrm{H}_{2} \mathrm{O}$ ligands facilitate the formation of $\mathrm{H}$-bonds with $\mathrm{O}$ atoms from the zeolite framework and then contribute to the binding energies. Coadsorption of $\mathrm{NH}_{3}$ and $\mathrm{H}_{2} \mathrm{O}$ provide complexes with a $\mathrm{CN}$ of two, only. Calculated phase diagrams clearly predict a preference for $\mathrm{Cu}^{\mathrm{I}}$ solvated by $2 \mathrm{NH}_{3}$ above $500 \mathrm{~K}$, and for $\mathrm{Cu}^{\mathrm{I}}$ solvated by $4 \mathrm{NH}_{3}$ below $500 \mathrm{~K}$ or for $\mathrm{Cu}^{\mathrm{I}}$ solvated by $2 \mathrm{NH}_{3}$ and $2 \mathrm{H}_{2} \mathrm{O}$ depending on the value of the pressure of water. Few stability domains are calculated for the adsorption of water on $\mathrm{Cu}^{\mathrm{I}}$ in SSZ-13. These findings are of crucial help to rationalize experimental trends made for example by operando XAS.

\section{ACKNOWLEDGMENTS}

Pr. Dr. Claudio M. Zicovich-Wilson, Michel Rerat and Dr. Raffaella Demichelis are acknowledge for helpful discussions. 
This work was performed using HPC resources from GENCI-[CCRT/CINES/IDRIS] (Grants No. 2010-x2011081071, A0010807394 and A0030807394).

\section{REFERENCES}

(1) Bell, A. T., Siting and stability of metal cations in zeolites. NATO Sci. Ser., II 2001, 13, $55-73$.

(2) Berthomieu, D.; Delahay, G., Recent advances in CuI/IIY: experiments and modeling. Catal. Rev. - Sci. Eng. 2006, 48 (3), 269-313.

(3) Beale, A. M.; Gao, F.; Lezcano-Gonzalez, I.; Peden, C. H. F.; Szanyi, J., Recent advances in automotive catalysis for NOx emission control by small-pore microporous materials. Chem. Soc. Rev. 2015, 44, 7371-7405.

(4) Dusselier, M.; Davis, M. E., Small-Pore Zeolites: Synthesis and Catalysis. Chem. Rev. (Washington, DC, U. S.) 2018, 118, 5265-5329.

(5) Kwak, J. H.; Tonkyn, R. G.; Kim, D. H.; Szanyi, J.; Peden, C. H. F., Excellent activity and selectivity of Cu-SSZ-13 in the selective catalytic reduction of NOx with NH3. J. Catal. 2010, 275 (2), 187-190.

(6) Kwak, J. H.; Zhu, H.; Lee, J. H.; Peden, C. H. F.; Szanyi, J., Two different cationic positions in Cu-SSZ-13? Chem. Commun. 2012, 48, 4758-4760.

(7) Borfecchia, E.; Beato, P.; Svelle, S.; Olsbye, U.; Lamberti, C.; Bordiga, S., Cu-CHA - a model system for applied selective redox catalysis. Chem. Soc. Rev. 2018, Ahead of Print. 
(8) Iwamoto, M.; Furukawa, H.; Mine, Y.; Uemura, F.; Mikuriya, S.; Kagawa, S., Copper(II) ion-exchanged ZSM-5 zeolites as highly active catalysts for direct and continuous decomposition of nitrogen monoxide. J. Chem. Soc., Chem. Commun. 1986, (16), 1272-3.

(9) Iwamoto, M.; Hamada, H., Removal of nitrogen monoxide from exhaust gases through novel catalytic processes. Catal. Today 1991, 10 (1), 57-71.

(10) Iwamoto, M.; Yahiro, H.; Mizuno, N.; Zhang, W. X.; Mine, Y.; Furukawa, H.; Kagawa, S., Removal of nitrogen monoxide through a novel catalytic process. 2. Infrared study on surface reaction of nitrogen monoxide adsorbed on copper ion-exchanged ZSM-5 zeolites. J. Phys. Chem. 1992, 96 (23), 9360-6.

(11) Iwamoto, M.; Yahiro, H.; Tanda, K.; Mizuno, N.; Mine, Y.; Kagawa, S., Removal of nitrogen monoxide through a novel catalytic process. 1. Decomposition on excessively copperion-exchanged ZSM-5 zeolites. J. Phys. Chem. 1991, 95 (9), 3727-30.

(12) Guenter, T.; Carvalho, H. W. P.; Doronkin, D. E.; Sheppard, T.; Glatzel, P.; Atkins, A. J.; Rudolph, J.; Jacob, C. R.; Casapu, M.; Grunwaldt, J.-D., Structural snapshots of the SCR reaction mechanism on Cu-SSZ-13. Chem. Commun. 2015, 51, 9227-9230.

(13) Kwak, J. H.; Varga, T.; Peden, C. H. F.; Gao, F.; Hanson, J. C.; Szanyi, J., Following the movement of $\mathrm{Cu}$ ions in a SSZ-13 zeolite during dehydration, reduction and adsorption: A combined in situ TP-XRD, XANES/DRIFTS study. J. Catal. 2014, 314, 83-93.

(14) McEwen, J. S.; Anggara, T.; Schneider, W. F.; Kispersky, V. F.; Miller, J. T.; Delgass, W. N.; Ribeiro, F. H., Integrated operando X-ray absorption and DFT characterization of Cu- 
SSZ-13 exchange sites during the selective catalytic reduction of NOx with NH3. Catalysis Today 2012, 184 (1), 129-144.

(15) Zhang, R.; McEwen, J.-S., Local Environment Sensitivity of the Cu K-Edge XANES Features in Cu-SSZ-13: Analysis from First-Principles. J. Phys. Chem. Lett. 2018, 9, 3035-3042.

(16) Bordiga, S.; Groppo, E.; Agostini, G.; van Bokhoven, J. A.; Lamberti, C., Reactivity of Surface Species in Heterogeneous Catalysts Probed by In Situ X-ray Absorption Techniques. Chem. Rev. 2013, 113, 1736-1850.

(17) Giordanino, F.; Borfecchia, E.; Lomachenko, K. A.; Lazzarini, A.; Agostini, G.; Gallo, E.; Soldatov, A. V.; Beato, P.; Bordiga, S.; Lamberti, C., Interaction of NH3 with Cu-SSZ-13 Catalyst: A Complementary FTIR, XANES, and XES Study. J. Phys. Chem. Lett. 2014, 5, 15521559.

(18) Marberger, A.; Petrov, A. W.; Steiger, P.; Elsener, M.; Kröcher, O.; Nachtegaal, M.; Ferri, D., Time-resolved copper speciation during selective catalytic reduction of $\mathrm{NO}$ on $\mathrm{Cu}-$ SSZ-13. Nature Catalysis 2018, 1 (3), 221-227.

(19) Andersen, C. W.; Borfecchia, E.; Bremholm, M.; Jorgensen, M. R. V.; Vennestrom, P. N. R.; Lamberti, C.; Lundegaard, L. F.; Iversen, B. B., Redox-Driven Migration of Copper Ions in the Cu-CHA Zeolite as Shown by the In Situ PXRD/XANES Technique. Angew. Chem., Int. Ed. 2017, 56, 10367-10372.

(20) Borfecchia, E.; Lomachenko, K. A.; Giordanino, F.; Falsig, H.; Beato, P.; Soldatov, A. V.; Bordiga, S.; Lamberti, C., Revisiting the nature of $\mathrm{Cu}$ sites in the activated Cu-SSZ-13 catalyst for SCR reaction. Chem. Sci. 2015, 6, 548-563. 
(21) Deka, U.; Juhin, A.; Eilertsen, E. A.; Emerich, H.; Green, M. A.; Korhonen, S. T.; Weckhuysen, B. M.; Beale, A. M., Confirmation of Isolated $\mathrm{Cu} 2+$ Ions in SSZ-13 Zeolite as Active Sites in NH3-Selective Catalytic Reduction. J. Phys. Chem. C 2012, 116, 4809-4818.

(22) Goltl, F.; Love, A. M.; Hermans, I., Developing a Thermodynamic Model for the Interactions between Water and $\mathrm{Cu}$ in the Zeolite SSZ-13. J. Phys. Chem. C 2017, 121, 61606169.

(23) Paolucci, C.; Khurana, I.; Parekh, A. A.; Li, S.; Shih, A. J.; Li, H.; Di Iorio, J. R.; Albarracin-Caballero, J. D.; Yezerets, A.; Miller, J. T.; Delgass, W. N.; Ribeiro, F. H.; Schneider, W. F.; Gounder, R., Dynamic multinuclear sites formed by mobilized copper ions in NOx selective catalytic reduction. Science 2017, 357 (6354), 898-903.

(24) Paolucci, C.; Parekh, A. A.; Khurana, I.; Di Iorio, J. R.; Li, H.; Albarracin Caballero, J. D.; Shih, A. J.; Anggara, T.; Delgass, W. N.; Miller, J. T.; Ribeiro, F. H.; Gounder, R.; Schneider, W. F., Catalysis in a Cage: Condition-Dependent Speciation and Dynamics of Exchanged Cu Cations in SSZ-13 Zeolites. J. Am. Chem. Soc. 2016, 138, 6028-6048.

(25) Paolucci, C.; Verma, A. A.; Bates, S. A.; Kispersky, V. F.; Miller, J. T.; Gounder, R.; Delgass, W. N.; Ribeiro, F. H.; Schneider, W. F., Isolation of the Copper Redox Steps in the Standard Selective Catalytic Reduction on Cu-SSZ-13. Angew. Chem., Int. Ed. 2014, 53, 1182811833.

(26) Martini, A.; Borfecchia, E.; Lomachenko, K. A.; Pankin, I. A.; Negri, C.; Berlier, G.; Beato, P.; Falsig, H.; Bordiga, S.; Lamberti, C., Composition-driven Cu-speciation and reducibility in $\mathrm{Cu}-\mathrm{CHA}$ zeolite catalysts: a multivariate XAS/FTIR approach to complexity. Chem. Sci. 2017, 8, 6836-6851. 
(27) Goltl, F.; Sautet, P.; Hermans, I., The impact of finite temperature on the coordination of $\mathrm{Cu}$ cations in the zeolite SSZ-13. Catal. Today 2016, 267, 41-46.

(28) Li, H.; Paolucci, C.; Schneider, W. F., Zeolite Adsorption Free Energies from ab Initio Potentials of Mean Force. J. Chem. Theory Comput. 2018, 14, 929-938.

(29) Moreno-Gonzalez, M.; Hueso, B.; Boronat, M.; Blasco, T.; Corma, A., AmmoniaContaining Species Formed in Cu-Chabazite As Per In Situ EPR, Solid-State NMR, and DFT Calculations. J. Phys. Chem. Lett. 2015, 6, 1011-1017.

(30) Herr, J. D.; Steele, R. P., Signatures of Size-Dependent Structural Patterns in Hydrated Copper(I) Clusters, $\mathrm{Cu}+(\mathrm{H} 2 \mathrm{O}) \mathrm{n}=1-10$. J. Phys. Chem. A 2016, 120, 10252-10263.

(31) Kispersky, V. F.; Kropf, A. J.; Ribeiro, F. H.; Miller, J. T., Low absorption vitreous carbon reactors for operando XAS: a case study on $\mathrm{Cu} /$ Zeolites for selective catalytic reduction of NO(x) by NH3. Phys Chem Chem Phys 2012, 14, 2229-38.

(32) Kerkeni, B.; Berthout, D.; Berthomieu, D.; Doronkin, D. E.; Casapu, M.; Grunwaldt, J. D.; Chizallet, C., Copper Coordination to Water and Ammonia in CuII-Exchanged SSZ-13: Atomistic Insights from DFT Calculations and in Situ XAS Experiments. J. Phys. Chem. C 2018, 122, 16741-16755.

(33) Calligaris, M.; Nardin, G., Cation site location in hydrated chabazites. Crystal structure of barium- and cadmium- exchanged chabazites. Zeolites 1982, 2, 200.

(34) Calligaris, M.; Nardin, G.; Randaccio, L., Cation site location in hydrated chabazites. Crystal structure of potassium- and silver- excahnged chabazites. Zeolites 1983, 3, 205. 
(35) Becke, A. D., A new mixing of Hartree-Fock and local-density-functional theories. $J$. Chem. Phys. 1993, 98 (2), 1372-7.

(36) Lee, C.; Yang, W.; Parr, R. G., Development of the Colle-Salvetti correlation-energy formula into a functional of the electron density. Phys. Rev. B: Condens. Matter 1988, 37 (2), 785-9.

(37) Dovesi, R.; Saunders, V. R.; Roetti, C.; Orlando, R.; Zicovich-Wilson, C. M.; Pascale, F.; Civalleri, B.; Doll, K.; Harrison, N. M.; Bush, I. J.; Arco, P. D.; Llunell, M. CRYSTAL09 Users Manual, University of Turin: Turin, 2009, see http://www.crystal.unito.it., 2009.

(38) Dovesi, R.; Orlando, R.; Erba, A.; Zicovich-Wilson, C. M.; Civalleri, B.; Casassa, S.; Maschio, L.; Ferrabone, M.; De La Pierre, M.; D’Arco, P.; Noel, Y.; M., C.; Rerat, M.; Kirtman, B., Int. J. Quantum Chem., 2014, 114, . 2014, 114, 1287-1317.

(39) Ducere, J.-M.; Goursot, A.; Berthomieu, D., Comparative density functional theory study of the binding of ligands to $\mathrm{Cu}+$ and $\mathrm{Cu} 2+$ : Influence of the coordination and oxidation state. $J$ Phys Chem A 2005, 109 (2), 400-8.

(40) Civalleri, B.; Zicovich-Wilson, C. M.; Valenzano, L.; Ugliengo, P., B3LYP augmented with an empirical dispersion term (B3LYP-D*) as applied to molecular crystals. CrystEngComm 2008, $10,405-410$.

(41) Grimme, S., Accurate description of van der Waals complexes by density functional theory including empirical corrections. J. Comput. Chem. 2004, 25, 1463-1473. 
(42) Boys, S. F.; Bernardi, F., The calculation of small molecular interactions by the differences of separate total energies. Some procedures with reduced errors. Mol. Phys. 1970, 19 , 553-566.

(43) Cramer, C. J., Essentials of Computational Chemistry: Theories and Models. John Wiley \& Sons Ltd: 2002; p 562 pp.

(44) Doronkin, D. E.; Casapu, M.; Guenter, T.; Mueller, O.; Frahm, R.; Grunwaldt, J.-D., Operando Spatially- and Time-Resolved XAS Study on Zeolite Catalysts for Selective Catalytic Reduction of NOx by NH3. J. Phys. Chem. C 2014, 118, 10204-10212.

(45) Goeltl, F.; Hafner, J., Structure and properties of metal-exchanged zeolites studied using gradient-corrected and hybrid functionals. II. Electronic structure and photoluminescence spectra. J.Chem. Phys. 2012, 136 (6),

(46) Perez-Badell, Y.; Solans-Monfort, X.; Sodupe, M.; Montero, L. A., A DFT periodic study on the interaction between $\mathrm{O}-2$ and cation exchanged chabazite $\mathrm{MCHA}(\mathrm{M}=\mathrm{H}+, \mathrm{Na}+$ or $\mathrm{Cu}+)$ : effects in the triplet-singlet energy gap. Physical Chemistry Chemical Physics 2010, 12 (2), 442452.

(47) Berthomieu, D.; Jardillier, N.; Delahay, G.; Coq, B.; Goursot, A., Experimental and theoretical approaches to the study of TMI-zeolite (TM=Fe, Co, Cu). Catal. Today 2005, 110 (34), 294-302.

(48) Jardillier, N.; Berthomieu, D.; Goursot, A.; Reveles, J. U.; Koster Andreas, M., Theoretical study of $\mathrm{Cu}(\mathrm{I}) \mathrm{Y}$ zeolite: structure and electronic properties. J Phys Chem B. 2006, $110(37), 18440-6$. 
(49) Chen, L.; Falsig, H.; Janssens, T. V. W.; Groenbeck, H., Activation of oxygen on (NH3Cu-NH3)+ in NH3-SCR over Cu-CHA. J. Catal. 2018, 358, 179-186. 